\title{
Benthos-Pelagos Interconnectivity: Antarctic Shelf Examples
}

\author{
Santiago E. A. Pineda-Metz
}

\begin{abstract}
This review focuses on studies dealing with the coupling between the benthic and pelagic realms on Antarctic shelves and on factors that regulate these processes. Such studies in Antarctic waters are scarce, especially on the shelves, where flux studies via moorings are highly endangered by drifting icebergs. Nevertheless, such studies are essential to understand these processes and functioning of the cold water ecosystem and how energy is transported through its different compartments. Different abiotic (e.g., currents, sea ice, water depth, topography of the seafloor, seasonality) and biotic (e.g., composition and structure of the benthic and pelagic flora and fauna, primary production, vertical migrations) factors are presented as parameters regulating the coupling between benthos and pelagos, here defined as benthos-pelagos interconnectivity. Regional variability in these parameters may result in delayed or even different coupling and/or decoupling of these realms. This is exemplarily discussed comparing the West Antarctic Peninsula (WAP) and Eastern Weddell Sea Shelf (EWSS). While in the WAP both compartments appear decoupled, on the EWSS both compartments appear tightly connected. The development of the benthos in the Larsen embayments after the shelf ice disintegration is described as an example of how changes in the pelagic realm affect and modify also the benthic realm.
\end{abstract}

\section{Keywords}

Bentho-pelagic coupling · Pelago-benthic coupling · Carbon flux · Weddell Sea Shelf · Antarctic Peninsula shelf

S. E. A. Pineda-Metz ( $\square)$

Alfred-Wegener-Institut Helmholtz-Zentrum für Polar- und

Meeresforschung, Bremerhaven, Germany

Universität Bremen (Fachbereich 2 Biologie/Chemie),

Bremen, Germany

e-mail: santiago.pineda.metz@awi.de

\subsection{Bentho-Pelagic or Pelago-Benthic Coupling? A Short Introduction}

When thinking of biotic (e.g., diversity, abundance, biomass) and abiotic (e.g., particle concentration, sediment grain size) parameters of both, benthic and pelagic realms, we start noticing lines or processes connecting them. One of the first studies on this connectivity was that of Hargrave (1973). He pointed out that both realms are connected by the flow of matter, especially that of carbon. Since that study, this interconnection between benthos and pelagos has been referred to as bentho-pelagic or pelago-benthic coupling. While the terms bentho-pelagic and pelago-benthic appear exchangeable, each one alludes to the predominant or driving component and direction in the coupling (Renaud et al. 2008). In bentho-pelagic coupling, it is the benthos which modifies or influences the pelagos. Contrastingly, in pelago-benthic coupling it is the pelagos which influences or modifies the benthos. In some literature bentho-pelagic coupling is referred to as "upward" coupling, while pelago-benthic coupling is referred to as "downward" coupling (e.g., Smith et al. 2006).

With this review, I aim to exemplify in a concise and simple way how benthos-pelagos interconnectivity, i.e., upward and downward coupling, works in the Southern Ocean with special focus on Antarctic shelf ecosystems (Fig. 11.1). My second aim is to enable non-experts to get a rough picture of the Antarctic benthos-pelagos interconnectivity.

\subsubsection{Pelago-benthic Coupling}

The first approaches used to describe the coupling between pelagos and benthos included measurements of carbon input from the water column to calculate how much of this carbon was assimilated in the sediment (Hargrave 1973). Currently, studies of downward mass flux are still the most common type of coupling studies (e.g., Cattaneo-Vietti et al. 1999; Smith et al. 2006, 2008; Isla et al. 2006a, b, 2011). Other 
Fig. 11.1 Map of the

Antarctic continent including locations mentioned in the review. (a) Austasen and Kapp Norvegia, EWSS; (b) Bransfield Strait and tip of the Antarctic Peninsula; (c)

McMurdo Sound, Ross Sea;

(d) Signy and Orcadas

Islands; (e) Rothera Point and area studied within the frame of the Food for Benthos on the Antarctic Continental Shelf (FOODBANCS) project in the West Aantarctic

Peninsula; and (f) Larsen

embayments, east coast of the Antarctic Peninsula.

(Modified after Arndt et al. (2013))

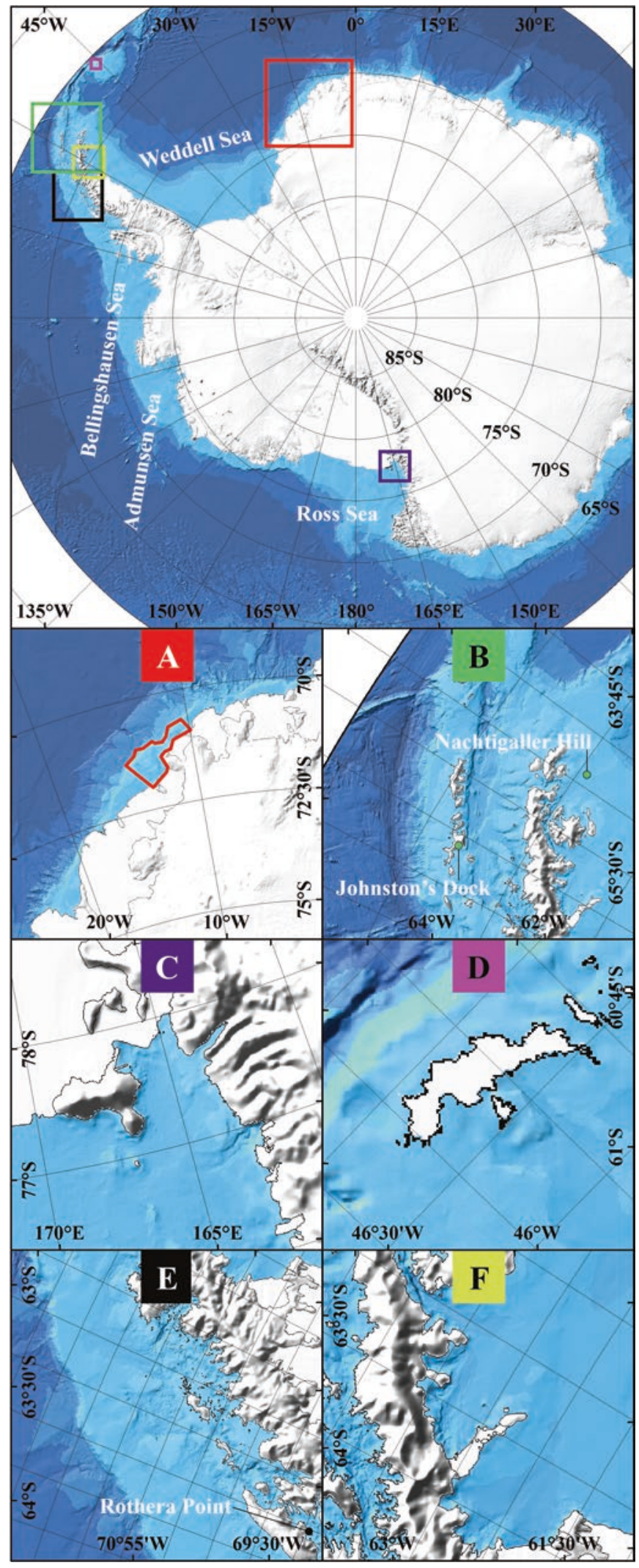


approaches to study pelago-benthic coupling include recruitment of benthic organisms via meroplanktonic larvae (Bowden 2005), change of sediment characteristics (Collier et al. 2000; Hauck et al. 2012; Isla 2016b), pelagic characteristics and seasonal patterns and how these affect benthic processes such as feeding activity (Barnes and Clarke 1995; McClintic et al. 2008; Souster et al. 2018), reproduction (Pearse et al. 1991; Stanwell-Smith et al. 1999; Brockington et al. 2001; Galley et al. 2005), growth rates and carbon fixed by benthos (Dayton 1989; Brey and Clarke 1993; Clarke 2003; Barnes et al. 2006, 2016, 2018; Barnes 2015), and benthic distribution patterns (Barry 1988; Barry and Dayton 1988; Graf 1989; Bathmann et al. 1991; Gutt et al. 1998; Sumida et al. 2008; Segelken-Voigt et al. 2016; Jansen et al. 2018)

\subsubsection{Bentho-pelagic Coupling}

Less common than pelago-benthic coupling studies are those that show an effect from the benthos to the pelagos, i.e., a bentho-pelagic coupling. One clear example of this "upward" coupling is the regulation of particulate matter flow in the benthic boundary layer by means of benthic structures (Graf and Rosenberg 1997; Mercuri et al. 2008; Tatián et al. 2008); another example of these processes is the increase of abundance and diversity of plankton by the release of meroplanktonic larvae from benthic organisms into the water (Bowden 2005; Schnack-Schiel and Isla 2005). Benthic processes also create feeding grounds for birds, seals, and zooplankton (Arntz et al. 1994; Ligowski 2000; Schmidt et al. 2011), they enhance primary production through export of micronutrients from remineralization and consumption/excretion processes of pelagic communities (Doering 1989; Smith et al. 2006; Schmidt et al. 2011), and can regulate the chemical characteristics of the water column (Doering 1989; Sedwick et al. 2000; Tatián et al. 2008).

\subsection{Regulating Factors of Benthic and Pelagic Processes}

In general terms, the interconnectivity between benthos and pelagos could be regarded as "weak" or "strong." This alludes to how directly changes in pelagos are reflected in benthos and vice versa. When seen as a correlation, it would be how strong the correlation between compartments is. The strength of the coupling between benthos and pelagos depends on seasonality in both compartments, the ecology and structure of benthic and pelagic communities, water depth, seafloor topography, water circulation (e.g., tides and currents), and wind, all affecting the transport of particles and thus carbon flux from one compartment to the other.
Around the Antarctic continent, another factor playing a major role for the regulation of this coupling between benthos and pelagos is the influence of ice in any of its forms (e.g., sea ice and disintegrated shelf ice, i.e., icebergs).

\subsubsection{Sea Ice}

The Southern Ocean is characterized by its large extension of sea ice, which covers up to $20 \times 10^{6} \mathrm{~km}^{2}$ during Austral winter and $4 \times 10^{6} \mathrm{~km}^{2}$ during summer (Fig. 11.2), making sea ice-associated ecosystems one of the most dynamic and largest ecosystems on Earth (Arrigo et al. 1997; Thomas and Dieckmann 2002; Michels et al. 2008). The retreat of sea ice during summer increases the water column stability, seeds summer phytoplankton blooms, and works as a source for micronutrients such as iron (as well as other particles), favoring phytoplankton blooms and explaining the higher productivity near sea ice edges as compared to open waters (Clarke 1988; Sedwick and DiTullio 1997; Sedwick et al. 2000; Kang et al. 2001; Donnelly et al. 2006). It has been shown that reduction of the sea ice duration also contributes to an increase of carbon drawdown by benthic organisms (Barnes 2015).

Sea ice starts growing during March to its enormous extension in Austral winter. The high coverage of sea ice and snow during winter time diminishes the light entering the water column, thus causing a drastic decrease in local productivity and particle flux (Scharek et al. 1994; Isla et al. 2006a). However, autotrophic plankton entrapped by sea ice during its formation (along with nutrients and consumers) continues primary production in winter time, which can be four to five times higher than water column production (Garrison and Close 1993). While lower than summer production, sea ice primary production has been pointed out to serve as a possible food source for meroplanktonic larvae (Bowden 2005) and various krill life stages (Nicol 2006; Kohlbach et al. 2017; Schaafsma et al. 2017). These few examples show how the sea ice summer/winter cycle regulates primary and secondary production in the water column and the particle flux, thus directly influencing the benthospelagos interconnectivity.

\subsubsection{Depth, Topography, Currents, and Wind}

One conspicuous aspect of the Antarctic shelf is its depth. While other shelf ecosystems in the world are shallower (down to around $200 \mathrm{~m}$ depth), the isostatic pressure generated by the ice cap on the Antarctic continent deepens the surrounding shelf down to 400-600 $\mathrm{m}$ and even down to 800-1000 $\mathrm{m}$ in some regions (Gallardo 1987; Smith et al. 2006; Sumida et al. 2008). Smith et al. (2006) pointed out 


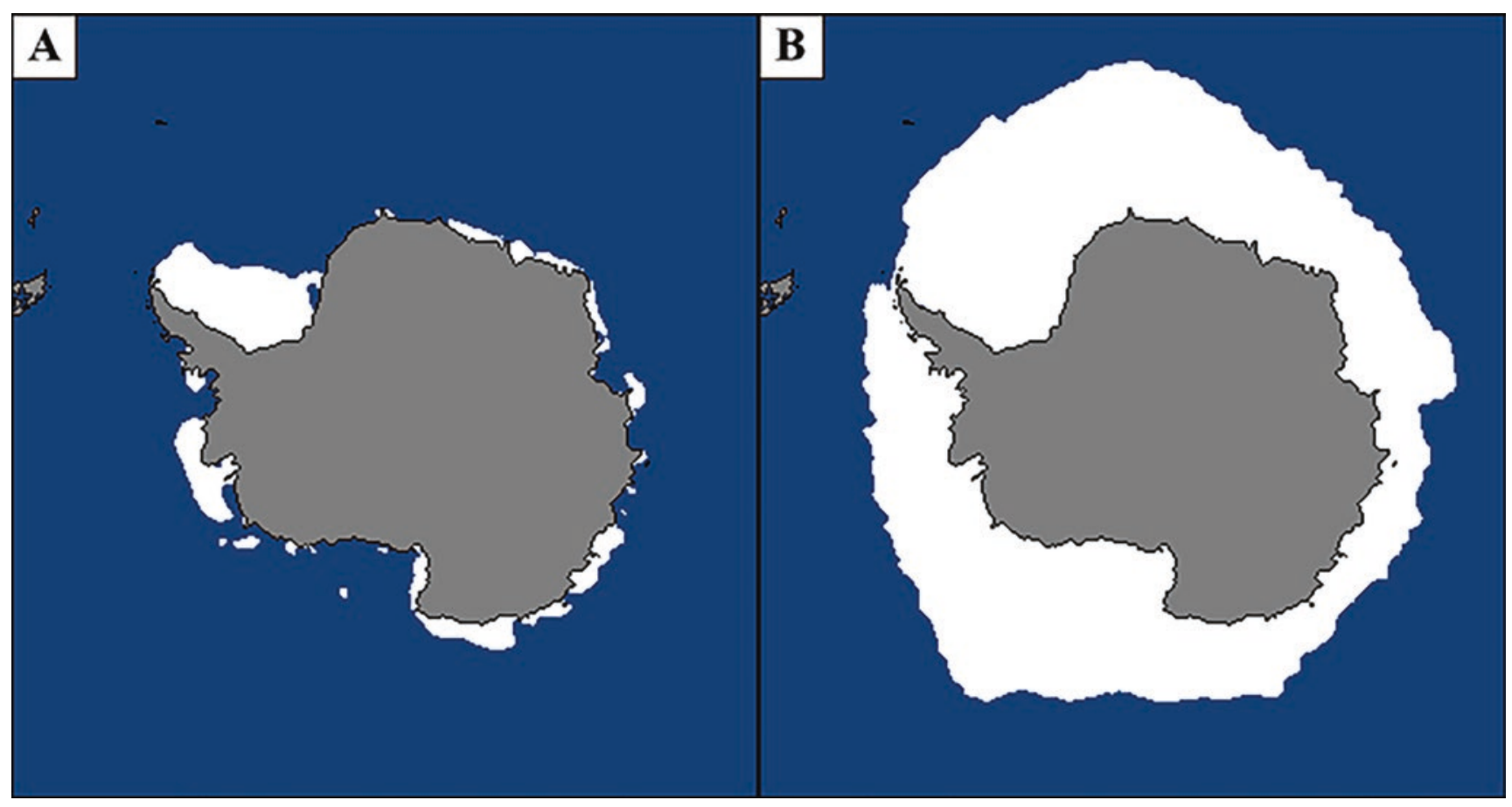

Fig. 11.2 Examples of sea ice extension during (a) summer (February 2018) and (b) winter (August 2018). (Modified after Fetterer et al. (2018))

that the increased depth of the Antarctic shelf with its complex topography and current systems may reduce the strength of the coupling by increasing the time particles spent in the water column, allowing local characteristics of the benthic habitat to mask the pelagic signals on the seafloor. However, the effect of depth on particle receding time in the water column will depend on the nature of the particles, e.g., on their flocculation ability, and other environmental factors such as wind forcing, which regulates deposition or advection of particles (biological factors are treated later). For the Eastern Weddell Sea Shelf (EWSS; Fig. 11.1a), it has been described that particle flux is rather fast. Total mass fluxes measured at mid-water and near the seafloor with sediment traps appeared to be similar, and it has been noted that particles can reach the seafloor within days despite the long 400-600 m depth trip from the euphotic zone to the seafloor (Bathmann et al. 1991; Isla et al. 2006a, 2009). For the Ross Sea, while Dunbar et al. (1998) recorded mean settling velocities of 176-245 $\mathrm{m} \mathrm{d}^{-1}$ for different types of fecal pellets, DiTullio et al. (2000) found aggregates of Phaeocystis antarctica to sink at speeds $>200 \mathrm{~m} \mathrm{~d}^{-1}$, i.e., it could take 1-3 days for pellets or Phaeocystis aggregates to reach the seafloor.

The topography of the shelf influences the benthospelagos interconnectivity as well. Topography affects benthic distribution patterns and the transport and deposition of particles suspended in the water column alike. Dorschel et al. (2014) pointed out that topographic features such as range hills, mounds, and seamounts modify water current pathways and their strength. Their study of the benthos at
Nachtigaller Hill (Fig. 11.1b) at the tip of the Antarctic Peninsula described depth as one main factor explaining benthic distribution patterns. They related this to food availability for the benthos, which could have been enhanced by the topography of Nachtigaller Hill. Another topographic feature affecting water currents is the width of the shelf. Along wider shelves the currents tend to be weaker; stronger currents are more usual when the shelf is narrow. Gutt et al. (1998) found relatively weaker current regimes on wider shelves of the EWSS to be beneficial for particle settling, which in turn benefits deposit-feeding organisms. Conversely, the narrower areas off Austasen and Kapp Norvegia (Fig. 11.1a) on the EWSS generate relatively stronger currents promoting resuspension of particles and thus being favorable for suspension feeder-dominated community types (Gutt et al. 1998).

Currents, tides, and advection of water parcels on the shelf also play a role in the benthos-pelagos interconnectivity. In some cases they weaken; in others they mask coupling processes between the compartments. An example can be drawn from the study of Isla et al. (2006b) at Johnston's Dock (Fig. 11.1b), where water current induced transport and advection of particles from shallower shelf areas enhance particle flux to deeper parts (Fig. 11.3). Other studies conducted in waters of the West Antarctic Peninsula (WAP) found particle flux on the deeper shelf to be enhanced by advected material originating from shallower shelves. This allochthonous input weakens the connection between benthic distribution patterns and metabolism of benthic organ- 


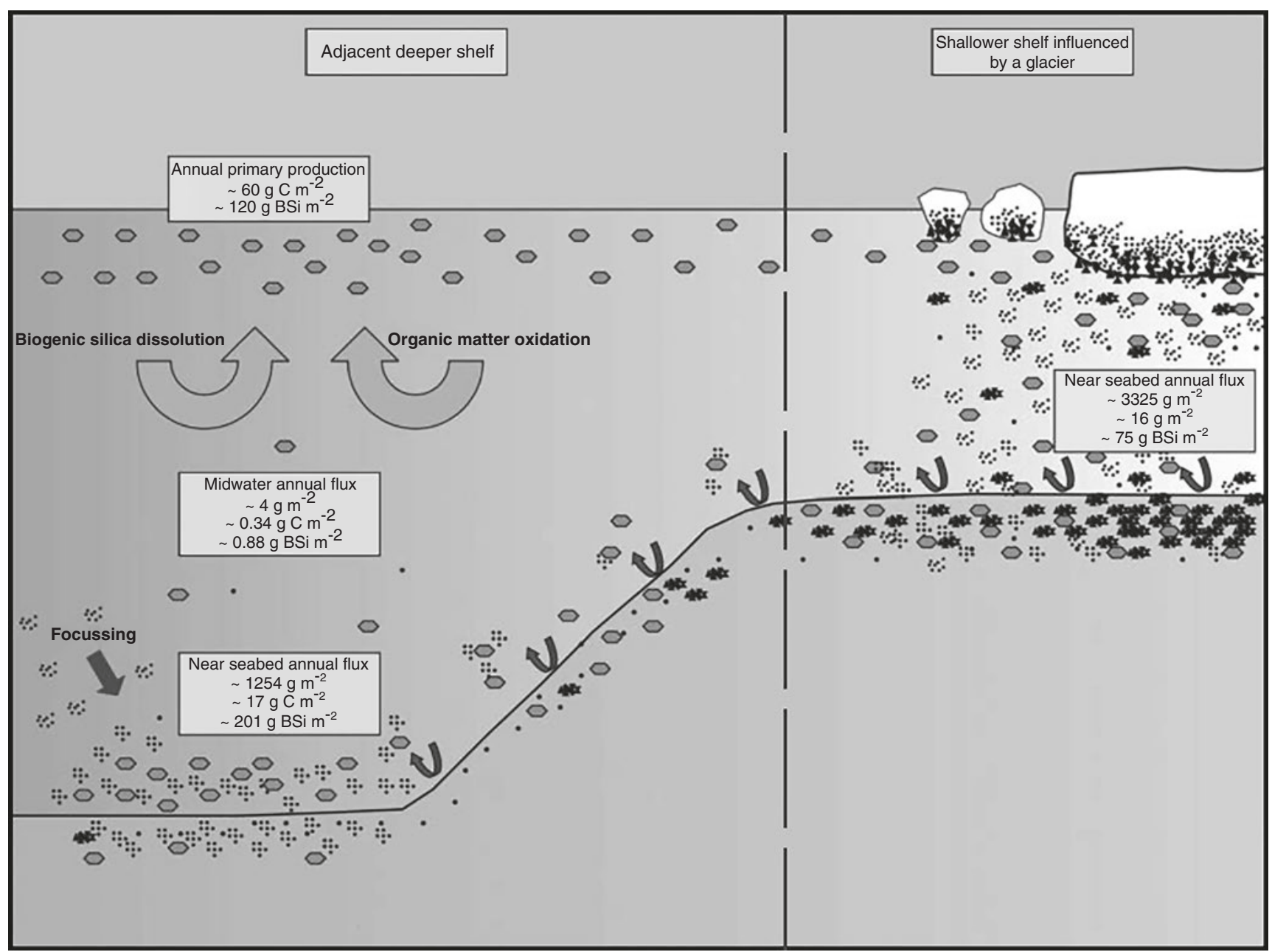

Fig. 11.3 Main particle fluxes at mooring sites around Johnston's Glacier (Johnston's Dock) studied by Isla et al. (2006b). Approximate annual total mass $\left(\mathrm{g} \mathrm{m}^{-2}\right)$, organic carbon $\left(\mathrm{g} \mathrm{C} \mathrm{m}^{-2}\right)$, and biogenic silica $\left(\mathrm{g} \mathrm{BSi} \mathrm{m}^{-2}\right)$ values are given. The sketch shows that most particles produced offshore over the deep shelf (polygons) do not reach mid-water; the material settling in the shallower shelf feeds the deeper shelf via

isms with primary production and local input of particles (McClintic et al. 2008; Sumida et al. 2008). Another clear example of the role of currents in the benthos-pelagos interconnectivity can be found in McMurdo Sound (Fig. 11.1c). Barry (1988) and Barry and Dayton (1988) found benthic distribution patterns to be coupled with primary production regimes and water circulation patterns. Circulation on the eastern side of McMurdo has a southward direction toward the Ross Ice Shelf and transports productive waters, which fuel rich benthic communities, whereas on the western side of the Sound, where less productive waters arrive from the ice shelf, a poorer benthic community is found.

Wind affects directly the benthos-pelagos interconnectivity by partly regulating sea ice and polynya formation, sea ice displacement, and mixed layer depth. While during winter periods, cold winds absorb heat from the water surface advection. Glacier and floating icebergs deliver coarse and fine sediments (dense clusters and circles, respectively) onto shallow areas, but mostly the latter reaches the deeper shelf. Near the seabed, resuspension of sediments is represented by curved arrows. (Modified after Isla et al. (2006b) with permission from Springer)

enhancing sea ice formation, in summer periods strong winds push away sea ice forming coastal polynyas (Isla 2016a). Wind-driven dispersal of the sea ice prior to its melting can prevent local release of algae trapped in the ice which would normally seed a local bloom (Riebesell et al. 1991). Furthermore, the strength of wind can also regulate the depth of the mixing layer in both a beneficial and prejudicial way. Where winds are relatively weaker, a shallower mix layer is formed (especially close to the ice edge). This shallower mix layer can foster larger blooms than deeper mixed layers (Ducklow et al. 2006). Conversely, in areas where winds are relatively stronger, a deeper mix layer is found. Deeper mixed layers can abruptly interrupt phytoplankton blooms, thus inhibiting primary production (Gleitz et al. 1994; Dunbar et al. 1998; Ducklow et al. 2006). While the deepening of the mix layer by wind action appears prejudicial for 
the coupling between pelagos and benthos by reducing primary production and thus its related particle flux, a deepening of the mix layer due to strong stormy winds has been pointed out to increase total downward particle flux. By means of sediment traps, Isla et al. (2009) found that strong stormy winds enhanced the transport of organic matter to the seabed. In their study, the flux resulting from a storm event which lasted a few days represented $53 \%$ of the total mass flux collected at mid-water during a period of 30 days.

\subsubsection{Seasonality and Particle Flux}

It is commonly accepted that the Antarctic benthic realm can be considered as a rather stable system with little variation in environmental parameters such as temperature, salinity, and water currents, whereas the pelagic realm is considered as highly seasonal with distinct summer/winter cycles, especially in primary production and sea ice extension (Gallardo 1987; Clarke 1988; Bathmann et al. 1991; Scharek et al. 1994; Arntz et al. 1994; Arrigo et al. 1998; Palanques et al. 2002; Smith et al. 2006; Isla et al. 2009, 2011; Rossi et al. 2013; Flores et al. 2014; Isla 2016b). While the stability of the benthos and instability of the pelagos are commonly accepted, the intrinsic biotic and abiotic factors of both are highly dependent on local water mass properties and circulation, as well as wind, sea ice, and topographic conditions (e.g., Barry and Dayton 1988; Barthel and Gutt 1992; Gleitz et al. 1994; Dunbar et al. 1998; Ducklow et al. 2006; Isla et al. 2009; Hauck et al. 2010; Barnes 2015).

\subsubsection{Pelagic Realm}

Primary production in the water column is key in regulating the flux of particles. Most of the primary production is proposed to be generated within the seasonal sea ice zone, especially in waters close to the retreating sea ice edge, where water column stability and nutrient concentrations are high. Driven by melting of sea ice, these locations also act as seeding grounds for primary production in the euphotic zone, enabled by released sea ice algae and enhanced input of nutrients (Scharek et al. 1994; Sedwick and DiTullio 1997; Sedwick et al. 2000; Arrigo et al. 2008; Bertolin and Schloss 2009; Isla et al. 2009; Isla 2016b). The primary production in the seasonal sea ice zone was estimated to be $1300 \mathrm{Tg} \mathrm{C} \mathrm{y}^{-1}$, of which $420 \mathrm{Tg} \mathrm{C}^{-1}$ are generated in the marginal sea ice zone and roughly $5 \%$ of production of the seasonal sea ice zone is produced by sea ice algae (Lizotte 2001). The importance of primary production regulating particle fluxes matches with zooplankton activities, because zooplankton quickly reacts to phytoplankton blooms (Flores et al. 2014). Grazing pressure is one of the main regulators of phytoplankton blooms. Fecal pellets resulting from this grazing largely contribute and regulate particle fluxes (Bathmann et al. 1991; Palanques et al. 2002; Isla et al. 2009; Rossi et al. 2013) and change the chemical composition of these fluxes and their size structure (Isla 2016b). Summer primary production and zooplanktonic grazing amount for $>95 \%$ of the yearly total mass flux. This particle flux provides carbon to the benthos, which equals between $<1$ up to $18 \%$ of the annual primary production of a region (Bathmann et al. 1991; Palanques et al. 2002; Isla et al. 2006a, 2009). Although the proportion of carbon reaching the seafloor appears negligible to low, it is still enough to support biomass-rich benthic communities and to form "food banks" (Gutt et al. 1998; Smith et al. 2006; Isla et al. 2009, 2011), as observed, e.g., on the EWSS, where benthic biomass is high and communities are mainly constituted by sessile suspension feeders (Gerdes et al. 1992; Gutt and Starmans 1998).

Vertical migration by zooplankton, fish, or diving vertebrates is regarded as a common feature of aquatic environments, and on an individual level, these provide a trade-off between nutrition and survival (Schmidt et al. 2011). In the context of this review, vertical migration refers to any causal vertical movement (e.g., foraging expeditions and avoidance of predators). The benthic realm works as feeding ground for various vertebrates, thus promoting vertical migrations. Arntz et al. (1994) pointed out that seals and penguins often dive deep to feed on benthic invertebrates. Antarctic krill Euphausia superba has also been found to migrate down to $3000 \mathrm{~m}$ depth either to feed on the seabed or as a result of being satiated (Ligowski 2000; Tarling and Johnson 2006; Schmidt et al. 2011). While migrating, swimming organisms release carbon and nutrients in form of feces. Release of feces near the benthos could mean an extra input of available food for benthic organisms. Conversely, excretion of a mix of benthic organic material and lithogenic particles in the upper water column would increase the concentration of labile iron which could enhance primary production (Schmidt et al. 2011).

\subsubsection{Deposition and Resuspension}

Specific particle composition and flux rates in a region are not just a question of primary production and associated zooplanktonic activity. They also are affected by local deposition and resuspension processes. Water currents, especially near the seabed, are one key environmental factor regulating deposition and resuspension. Another key environmental factor are icebergs. Iceberg scours change the seabed topography, affect the near seabed current regime, and modify the deposition regime in the area by trapping particles in the scours mark (working as a sort of "sediment trap"). Iceberg scour marks can be 10 s to 100 s meters wide, several meters deep, and 10s of meters or even kilometers long (Gutt 2001; Gerdes et al. 2003). On the other hand, iceberg scours can also enhance resuspension by generating an upward particle flux (Gutt 2001; Barnes et al. 2018). 
A recent study on the effect of icebergs and sea ice on "blue carbon" (carbon in organisms) pointed out that in March 2017, 47 giant icebergs larger than $30 \mathrm{~km}^{2}$ occurred in Antarctica, 6 of which exceeded $1000 \mathrm{~km}^{2}$ in area (Barnes et al. 2018). Initially, any iceberg scour would resuspend already fixed blue carbon and increase the open water area by breaking and displacing sea ice. The combination of additional resuspended material and open water area would result in an increase of primary production, which in turn would promote benthic growth. As a result, deposition would be increased not only by the enhanced primary production but also by the proportional increase of benthic suspension feeder biomass (Barnes et al. 2018).

The studies of Mercuri et al. (2008), Tatián et al. (2008), and Barnes et al. $(2016,2018)$ are examples of how benthic organisms affect deposition and resuspension. Micro-, macro-, and megafauna as well as marine flora directly affect the sediment erodibility and regulate sediment mixing, which greatly affects the benthos-pelagos interconnectivity (Orvain et al. 2012; Queirós et al. 2015). Benthic organisms may decrease sediment roughness by mucus, bacterial mats, or diatom film production, thus reducing the resuspension ability of sediments (de Jonge and van den Bergs 1987; Grant and Bathmann 1987; Paterson 1989; Self et al. 1989; Delgado et al. 1991; Dade et al. 1992; de Jonge and van Beusekom 1995). In Antarctic benthos, hexactinellid sponges exemplify how organisms can reduce resuspension and enhance deposition. These sponges cement and consolidate sediments, enhance biodiversity by promoting the immigration of other sponge species, provide refuges to other taxa, and generate spicule mats (Fig. 11.4), which work as silicon traps (Barthel 1992; Barthel and Gutt 1992; Gutt et al. 2013a). Sponges and other filter feeders collect particles from the water column, thus enhancing the downward flux of particles and their deposition (Barthel 1992; Mercuri et al. 2008; Tatián et al. 2008). This biodeposition effect is enhanced by the increase of biodiversity provided by sponges. Furthermore, spicule mats reduce resuspension by covering the sediment, thus reducing its erodibility. Other structures that enhance deposition are tube formations (Fig. 11.4). High density of polychaete tubes could generate an attracting effect equal to that of baffles in sediment traps, albeit in a reduced area (Frithsen and Doering 1986). Contrastingly, other activities of benthic organisms such as pellet production and bioturbation with formation of mounds, pits, tubes, and tracks can change the sediment structure and enhance particle resuspension (Eckman et al. 1981; Eckman and Nowell 1984; Luckenbach 1986; Davis 1993). Resuspended material tends to be rich in nutrients and contains also micronutrients such as iron, which could, in shallower shelf areas with upwelling or those shelf areas where deep mixing occur, enhance summer primary production (Doering 1989; Sedwick et al. 2000).

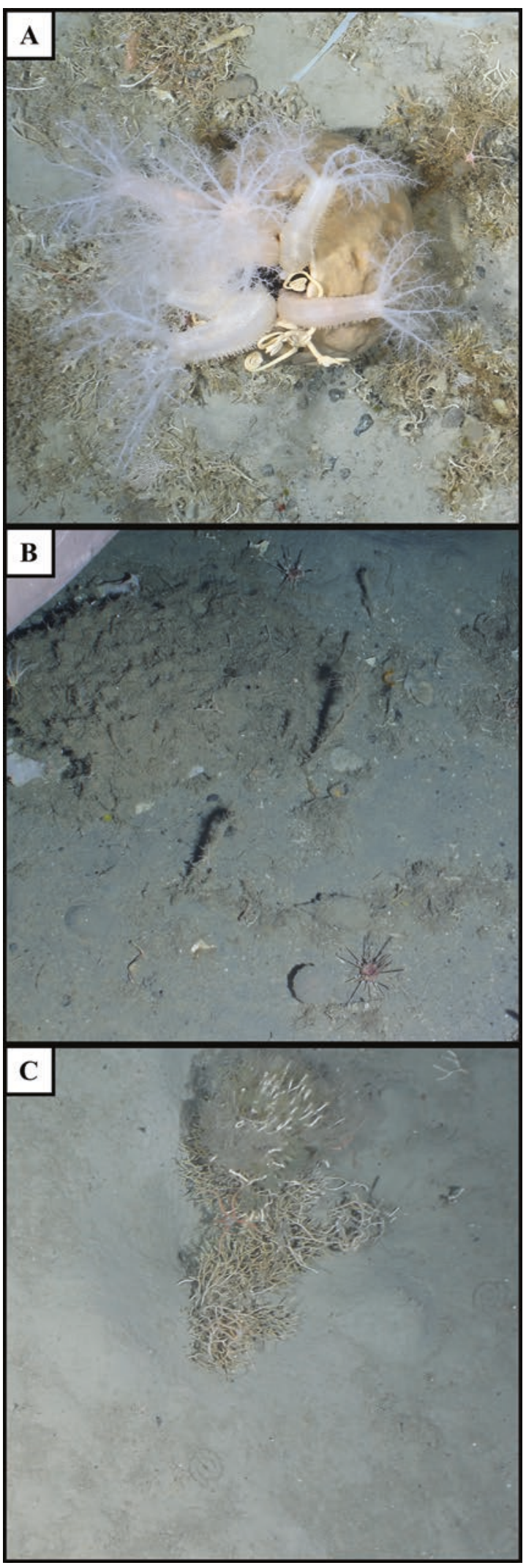

Fig. 11.4 Examples of benthic structures which modify particle resuspension and deposition: (a) a three-dimensional structure provided by sponges and associated organisms; (b) a spicule mat covering part of the seabed; and C) a cluster of polychaete tubes. Images (a) and (c) were modified after Piepenburg (2016). Image (b) was kindly provided by $\mathrm{D}$. Gerdes and modified 


\subsubsection{Benthic Realm}

The marked seasonal differences in the pelagic realm, especially the reduction of carbon flux in winter (see Sects. 11.2.1 and 11.2.3.1), has been thought to directly regulate benthic processes such as reproduction, growth, feeding activity, sexual development, recruitment of juveniles, and also benthic distribution patterns. However, studies on bentho-pelagic and pelago-benthic coupling in Antarctic waters have shown differences between benthic and pelagic seasonality to be less important in regulating benthic processes and that both compartments could be less coupled than thought, partly due to the effect of currents, lateral advection, and tides (see Sect. 11.2.2). Stanwell-Smith et al. (1999) studied meroplanktonic larvae released by benthic organisms and described these larvae to be present throughout the year. In some cases, the larval peak was clearly decoupled from the summer bloom, and the recruitment of benthic organisms was described to occur year-round or with a tendency to happen during winter months (Bowden 2005; Galley et al. 2005). Similarly, Sumida et al. (2008) found recruitment of holothurians to occur during winter, but these deposit feeders were actively feeding throughout the whole year. Measurements of metabolic activity via thorium (Th) isotopes made by McClintic et al. (2008) confirmed benthos to be metabolically active year-round. Results from the studies of Sumida et al. (2008) and McClintic et al. (2008) conducted in the WAP agreed with earlier findings made by Barnes and Clarke (1995), who recorded feeding activities of bryozoans, holothurians, polychaetes, and hydroids at Signy Island (Fig. 11.1d). However, Barnes and Clarke (1995) did not find any feeding activity during short periods of time during winter. Similarly, a study conducted at Rothera Point (Fig. 11.1e) by Brockington et al. (2001) on the feeding activity and nutritional status of the sea urchin, Sterechinus neumayeri, found this species to completely stop feeding during winter. In a recent study, Souster et al. (2018) measured the seasonality of oxygen consumption of five benthic invertebrates and found the oxygen consumption of suspension and deposit feeders to be independent from the input provided by the local summer flux. It has been proposed that benthic organisms can feed or be metabolically active year-round by changing their feeding mechanism, as is known for some sponges, polychaetes, bivalves, and cnidarians (Cattaneo-Vietti et al. 1999; Orejas et al. 2001).

\subsection{Regional Patterns in Coupling Processes}

The interaction between biotic and abiotic factors regulating the benthos-pelagos interconnectivity will have direct implications on how "strong" or "weak" the coupling between realms is and how changes in one of the compartments may affect its counterpart. When comparing different Antarctic regions, we observe differences in flux regulators and in the structure of the respective benthic communities. These differences reflect how variable the strength of the coupling between benthos and pelagos is. To exemplify how coupled or decoupled systems appear, I compared data obtained in WAP and EWSS waters. Furthermore, I include the example of the Larsen area (Fig. 11.1f) to exemplify how changes in the pelagos affect and modify the benthos.

\subsubsection{West Antarctic Peninsula}

To describe the benthos-pelagos interconnectivity on the WAP shelf, I focused on studies from the Bransfield Strait (Palanques et al. 2002; Isla et al. 2006b), Rothera Point (Souster et al. 2018), and those conducted within the frame of the "Food for Benthos on the Antarctic Continental Shelf" project (FOODBANCS; e.g., Smith et al. 2006; McClintic et al. 2008; Sumida et al. 2008). All locations are marked in Fig. $11.1 \mathrm{~b}$, e. According to these studies, the coupling between the pelagic primary production and benthic biological processes in these areas appears "weak." As already stated, the study of McClintic et al. (2008) with Th isotopes not only showed benthos to be metabolically active the whole year; it also showed that the delivery of this isotope to the sediment was not related to local downward flux, suggesting more influence from advected material than from local production. Investigation of the shelf fauna via video recordings (Sumida et al. 2008, 2014) also shows proof of a "weak" local coupling. They found holothurians to recruit during winter, i.e., independently from local food input. Sumida et al. $(2008,2014)$ also recorded feces of holothurian yearround, but with hints to higher feeding rates during summer, which appears to be the result of better food quality in this season (Sumida et al. 2014). The study of Souster et al. (2018) found results partly different to those of Sumida et al. (2008, 2014). Souster et al. (2018) described primary consumers (suspension and deposit feeders) to maintain a rather stable metabolic activity year-round, regardless of food input, while secondary consumers (scavengers and predators) showed higher metabolic activity during summer than winter. These authors attributed the seasonal metabolic differences of secondary consumers to be related to better quality of food items rather than to their quantity.

Studies conducted in the WAP evidence advection of material to be more important than locally produced particle fluxes. Palanques et al. (2002) found a high amount of the sediments captured by their traps located in the deeper Bransfield Strait (BS; Fig. 11.1b) to originate from shallower areas of the BS. The sediment fluxes near the bottom 
accounted for $18 \%$ of the annual primary production, and these fluxes included benthic organisms and particles resuspended and laterally transported from shallower adjacent areas. The study of Isla et al. (2006b) found that sedimentation generated by the Johnson's Glacier (Johnson's Dock, Fig. 11.1b) was comprised mostly of fine sediment. These particles were rich in organic matter, and near-bottom lateral transport of this resuspended matter was the main source of carbon flux into deeper basins (Isla et al. 2006b). These evidences suggest the shallow coastal areas of the WAP to be highly nutritive. Via advection from these shallower areas, the adjacent deeper basins are provided with organic matter. This material is accumulated and forms green mats or "food banks." These green mats ensure the presence of food for benthos during the low production autumn and winter seasons (Smith et al. 2006). The formation of these "food banks" via advected material and a dominance of deposit feeders might explain the restricted meaning of locally generated particle fluxes between pelagic and benthic realms in the WAP (McClintic et al. 2008; Sumida et al. 2008; Souster et al. 2018).

\subsubsection{Eastern Weddell Sea Shelf}

The "weak" interconnectivity in the WAP appears to be connected to how particle fluxes are mainly regulated by advection processes from shallower shelves to deeper basins, where "food banks" are formed (Isla et al. 2006b; Smith et al. 2006; McClintic et al. 2008; Sumida et al. 2008). On the EWSS, downward particle transport off Austasen and Kapp Norvegia (Fig. 11.1a) has been described to be fast (Bathmann et al. 1991; Isla et al. 2009), despite the relatively stronger currents caused by the narrow shelf. This "fast" downward flux is evidenced by (a) how sediments quickly reflect the local bloom and its associated characteristics (Bathmann et al. 1991; Isla et al. 2009) and (b) how bottom sediments are especially nutritive during summer/autumn (Isla et al. 2011). The efficient transport of carbon from the pelagic to the benthic realm in combination with the resus-

Table 11.1 Depth ranges and wet weight biomass data $\left(\mathrm{g}_{\mathrm{ww}} \mathrm{m}^{-2)}\right.$ from multi-box corer samples collected in four subregions of the Weddell Sea: Tip of the Antarctic Peninsula (TAP), Larsen embayments (LA), Filchner Region (FR), and Eastern Weddell Sea Shelf (EWSS) (S.E.A. Pineda-Metz, unpublished data)

\begin{tabular}{l|l|l|l|l}
\hline Subregion & Depth range $(\mathrm{m})$ & \multicolumn{3}{|l}{ Biomass $\left(\mathrm{g}_{\mathrm{ww}} \mathrm{m}^{-2}\right)$} \\
\hline & & Range & Mean & Median \\
\hline TAP & $187-934$ & $30-3485$ & 423 & 223 \\
\hline LA & $202-850$ & $2-786$ & 78 & 16 \\
\hline FR & $254-1217$ & $1-335$ & 51 & 24 \\
\hline EWSS & $248-1486$ & $1-103,235$ & 4811 & 134 \\
\hline
\end{tabular}

pension of particles could explain the benthic community characteristic on the EWSS. Benthic communities in this region have been described as rich in sessile suspension feeders, especially glass sponges, which not only increase diversity by creating three-dimensional structures with space for many other species but also explain the high biomass of the EWSS benthos, which is higher than that of other subregions in the Weddell Sea including the tip of the Antarctic Peninsula (Table 11.1; Barthel 1992; Barthel and Gutt 1992; Gerdes et al. 1992; Arntz et al. 1994; Gutt and Starmans 1998; Sañé et al. 2012; Gerdes 2014a, b; S.E.A. Pineda-Metz unpublished data). This high biomass of suspension feeders also influences deposition and sediment chemistry. It seems feasible that suspended particles are largely consumed by suspension feeders, thus transforming the chemical composition of these particles and reducing the amount of organic carbon remaining for incorporation into the sediment. The efficient local flux patterns in combination with particle resuspension and high biomass of suspension feeders which benefit from these conditions might explain the "stronger" coupling between benthic and pelagic realms on the EWSS contrarily to what was found in the WAP region.

\subsubsection{The Changing Situation of Larsen}

The Larsen embayments on the eastern coast of the Antarctic Peninsula (Fig. 11.1f) may serve as an example of how changes in the pelagic system influence benthos. Studies in the embayments formerly covered by the Larsen A and B ice shelves reflected a shift from an oligotrophic system to one with enhanced production and flux rates (Sañé et al. 2011). Before the disintegration of the shelf ice in 1995 and 2002, respectively, the shelf benthos appeared impoverished and in an early developmental stage as compared to the EWSS. Sessile suspension feeders showed low biomasses, and several deep-sea species on the shelf reflected the oligotrophic conditions resembling the deep sea (Gutt et al. 2011; Sañé et al. 2012; Gerdes 2014a, b). The disintegration of shelf ice created new space offshore for enhanced local primary production, shifting toward a more eutrophic and productive pelagic realm (Bertolin and Schloss 2009). Within a relatively short time, this enhanced pelagic production led to a shift also in the composition of the benthos (Fillinger et al. 2013; Gutt et al. 2013b). Benthos shifted from an ascidian dominated to a sponge- and ophiuroid-dominated fauna. Suspension-feeding ophiuroids were replaced by a more abundant deposit-feeding ophiuroid fauna, and sponges increased two- to threefold in terms of abundance and biomass (Fillinger et al. 2013; Gutt et al. 2013b). 


\subsection{Outlook}

Studies on the coupling between the benthic and pelagic realms are difficult approaches with complex sampling programs, which require similar temporal and spatial scales for drawing accurate conclusions about coupling processes and their meaning for both compartments (Raffaelli et al. 2003; Renaud et al. 2008). This review on benthos-pelagos interconnectivity includes attempts to describe regulating factors that connect the benthic and pelagic both realms.

Based on "real data", I draw assumptions to distinguish between specific coupling processes in different Antarctic regions. These assumptions are made on only few studies, which were not all intended to study the benthos-pelagos interconnectivity per se but aimed to study processes individually. This implies that my hypothetical assumptions need further testing. This shows also that many gaps remain and filling them will be of paramount importance to better understand how both realms are connected and how carbon cycling works on Antarctic shelves.

There have been a series of attempts to connect the Antarctic benthic and pelagic realms, reflected (but not restricted) to the works of Barry (1988) Barry and Dayton (1988), Dayton (1989), Ligowski (2000), Schnack-Schiel and Isla (2005), Barnes et al. (2006, 2016, 2018), Isla et al. (2006a; b), Smith et al. (2006, 2008), McClintic et al. (2008), Mercuri et al. (2008), Tatián et al. (2008), Schimdt et al. (2011), Sañé et al. (2011, 2012), Barnes (2015), Jansen et al. (2018), and Souster et al. (2018). Promising attempts to fill regional gaps have also been made. The FOODBANCS project (Smith et al. 2006, 2008) gives a clear hint of how the coupling (or decoupling) between benthos and pelagos works in shelves of the WAP. In this modern age, modelling has gained great importance. Models on how pelagic particles are distributed and are related to benthic distribution patterns are starting to be developed (e.g., Jansen et al. 2018). While promising, attempts on modelling and correlating benthic and pelagic processes are still in early stages. Other Antarctic areas with a long history of studies such as the Weddell Sea need the available data to be reviewed, sorted, and used to start drawing lines between benthic and pelagic realms, as attempted in this review. This first step will help to set the course of future studies and point out a red line on how benthos-pelagos interactions could be investigated in different Antarctic regions, which in turn will provide an excellent tool to understand how the ongoing and predicted climate change will affect the Antarctic shelves.

Acknowledgments I would like to thank the organizers of the YOUMARES 9 conference for giving me the opportunity not only to work on this manuscript but also to organize the session "Connecting the bentho-pelagic dots." Also thanks to Chester Sands and another anonymous reviewer who took the job of greatly improving this review. I also feel deeply grateful to Dieter Gerdes, without whom this manuscript would look a lot messier and harder to read as it is. Many thanks go also to L. Metz, M. Pineda, and H. Costa, who founded part of my work. Last, but not least, thanks to the staff of the CPT $N^{\circ} 704$, who helped me to start paying attention to the full picture some years ago.

\section{Appendix}

This article is related to the YOUMARES 9 conference session no. 14: "Connecting the bentho-pelagic dots." The original Call for Abstracts and the abstracts of the presentations within this session can be found in the Appendix "Conference Sessions and Abstracts", Chapter "10 Connecting the bentho-pelagic dots", of this book.

\section{References}

Arndt JE, Schenke HW, Jakobsson M et al (2013) The international bathymetric chart of the Southern Ocean (IBCSO) version $1.0-\mathrm{a}$ new bathymetric compilation covering circum-Antarctic water. Geophys Res Lett 40:3111-3117. https://doi.org/10.1002/grl.50413

Arntz WE, Brey T, Gallardo VA (1994) Antarctic zoobenthos. Oceanogr Mar Biol 32:241-304

Arrigo KR, Worthen DL, Lizotte MP et al (1997) Primary production in Antarctic Sea ice. Science 276(5311):394-397. https://doi. org/10.1126/science.276.5311.394

Arrigo KR, Worthen DL, Schnell A et al (1998) Primary production in Southern ocean waters. J Geophys Res 103:15587-11560. https:// doi.org/10.1028/1998JC000289

Arrigo KR, van Dijken GL, Bushinsky S (2008) Primary production in the Southern Ocean, 1997-2006. J Geophys Res 113:C08004. https://doi.org/10.1029/2007JC004551

Barnes DKA (2015) Antarctic Sea ice losses drive gains in benthic carbon drawdown. Curr Biol 25:R775-R792

Barnes KA, Clarke A (1995) Feeding activity in Antarctic suspension feeders. Polar Biol 15:335-340

Barnes DKA, Webb K, Linse K (2006) Slow growth of Antarctic bryozoans increases over 20 years and is anomalously high in 2003. Mar Ecol Prog Ser 314:187-195

Barnes DKA, Ireland L, Hogg OT et al (2016) Why is the South Orkney Island shelf (the world's first high seas marine protected area) a carbon immobilization hotspot? Glob Change Biol 22:1110-1120. https://doi.org/10.1111/gcb.13157

Barnes DKA, Fleming A, Sands CJ et al (2018) Icebergs, sea ice, blue carbon and Antarctic climate feedbacks. Phil Trans R Soc A 376:2017176. https://doi.org/10.1098/rsta.2017.0176

Barry JP (1988) Hydrographic patterns in McMurdo Sound, Antarctica and their relationship to local benthic communities. Polar Biol 8:377-391

Barry JP, Dayton PK (1988) Current patterns in McMurdo Sound, Antarctica and their relationship to local biotic communities. Polar Biol 8:367-376

Barthel D (1992) Do hexactinellids structure Antarctic sponge associations? Ophelia 36:111-118

Barthel D, Gutt J (1992) Sponge associations in the eastern Weddell Sea. Antarct Sci 4:157-150

Bathmann E, Fischer G, Müller PJ et al (1991) Short-term variations in particulate matter sedimentation off Kapp Norvegia, Weddell Sea, 
Antarctica: relation to water mass advection, ice cover, plankton biomass and feeding activity. Polar Biol 11:185-195

Bertolin ML, Schloss IR (2009) Phytoplankton production after the collapse of the Larsen a ice shelf. Antarct Polar Biol 32:1435-1446. https://doi.org/10.1007/s00300-009-638-x

Bowden DA (2005) Seasonality of recruitment in Antarctic sessile marine benthos. Mar Ecol Prog Ser 297:101-118

Brey T, Clarke A (1993) Population dynamics of marine benthic invertebrates in Antarctic and subantarctic environments: are there unique adaptations? Antarct Sci 5(3):253-266. https://doi.org/10.1017/ S0954102093000343

Brockington S, Clarke A, Chapman ALG (2001) Seasonality of feeding and nutritional status during the austral winter in the Antarctic Sea urchin Sterechinus neumayeri. Mar Biol 139:127-138

Cattaneo-Vietti R, Chiantore MC, Misic C et al (1999) The role of pelagic-benthic coupling in structuring littoral benthic communities at Terra Nova Bay (Ross Sea) and in the Straits of Magellan. Sci Mar 63(1):113-121

Clarke A (1988) Seasonality in the Antarctic marine environment. Comp Biochem Physiol B 90(3):461-473

Clarke A (2003) Costs and consequences of evolutionary temperature adaptation. Trends Ecol Evol 18(11):573-581

Collier R, Dymond J, Honjo S et al (2000) The vertical flux of biogenic and lithogenic material in the Ross Sea: Moored sediment trap observations 1996-1998. Deep-Sea Res II 47:3491-3520

Dade WB, Nowell ARM, Jumars PA (1992) Predicting erosion resistance of muds. Mar Geol 105:285-297

Davis WR (1993) The role of bioturbation in sediment resuspension and its interaction with physical shearing. J Exp Mar Biol Ecol 171:187-200

Dayton PK (1989) Interdecadal variation in an Antarctic sponge and its predators from oceanographic climate shifts. Science 245:1484-1486

de Jonge VN, van Beusekom JEE (1995) Wind- and tide-induced resuspension of sediment and microphytobenthos from tidal flats in the Ems estuary. Limnol Oceanogr 40:766-778

de Jonge VN, van den Bergs J (1987) Experiments on the resuspension of estuarine sediments containing benthic diatoms. Estuar Coastal Shelf Sci 24:725-740

Delgado M, de Jonge VN, Peletier H (1991) Experiments on resuspension of natural microphytobenthos populations. Mar Biol 108:321-328

DiTullio GR, Grebmeier JM, Arrigo KR et al (2000) Rapid and early export of Phaeocystis Antarctica blooms in the Ross Sea, Antarctica. Nature 404:595-598

Doering P (1989) On the contribution of the benthos to pelagic production. J Mar Res 47:371-383

Donnelly J, Sutton TT, Torres JJ (2006) Distribution and abundance of micronekton and microzooplankton in the NW Weddell Sea: relation to a spring ice-edge bloom. Polar Biol 29:280-293. https://doi org/10.1007/s00300-005-0051-z

Dorschel B, Gutt J, Piepenburg D et al (2014) The influence of the geomorphological and sedimentological settings on the distribution of epibenthic assemblages on a flat topped hill on the over-deepened shelf of the western Weddell Sea (Southern Ocean). Biogeosciences 11:3797-3817. https://doi.org/10.5194/bg-11-3797-2014

Ducklow HW, Frase W, Karl DM et al (2006) Water-column processes in the West Antarctic Peninsula and the Ross Sea: interannual variations and foodweb structure. Deep-Sea Res II 53:834-852

Dunbar RB, Leventer AR, Mucciarone DA (1998) Water column sediment fluxes in the Ross Sea, Antarctica: atmospheric and sea ice forcing. J Geophys Res 103:30741-30759

Eckman JE, Nowell ARM (1984) Boundary skin friction and sediment transport about an animal-tube mimic. Sedimentology 31:851-862

Eckman JE, Nowell ARM, Jumars PA (1981) Sediment destabilization by animal tubes. J Mar Res 39:361-374
Fetterer F, Knowles K, Meier W et al (2018) Sea Ice Index, Version3 [February and August 2018]. NSIDC: National Snow and Ice Data Center, Boulder. https://doi.org/10.7265/N5K072F8. Accessed 11 Oct 2018

Fillinger L, Janussen D, Lundäalv T et al (2013) Rapid glass sponge expansion after climate-induced Antarctic ice shelf collapse. Curr Biol 23:1330-1334. https://doi.org/10.1016/j.cub.2013.05.051

Flores H, Hunt BPV, Kruse S et al (2014) Seasonal changes in the vertical distribution and community structure of Antarctic macrozooplankton and micronekton. Deep-Sea Res I 84:127-141

Frithsen JB, Doering PH (1986) Active enhancement of particle removal from the water column by tentaculate benthic polychaetes. Ophelia 25:169-182

Gallardo VA (1987) The sublittoral macrofaunal benthos of the Antarctic shelf. Environ Int 13:71-81

Galley EA, Tyler PA, Clarke A et al (2005) Reproductive biology and biochemical composition of the brooding echinoid Amphipneustes lorioli on the Antarctic continental shelf. Mar Biol 148:59-71. https://doi.org/10.1007/s00227-005-0069-3

Garrison DL, Close AR (1993) Winter ecology of the sea ice biota in Weddell Sea pack ice. Mar Ecol Prog Ser 96:17-31

Gerdes D (2014a) Biomass of macrozoobenthos in surface sediments sampled during POLARSTERN cruise ANT-XXIII/8. Alfred Wegener Institute, Helmholtz Center for Polar and Marine Research, Bremerhaven, PANGAEA. https://doi.org/10.1594/ PANGAEA.834054. Accessed 20 Aug 2015

Gerdes D (2014b) Biomass of macrozoobenthos in surface sediments sampled during POLARSTERN cruise ANT-XXVII/3. Alfred Wegener Institute, Helmholtz Center for Polar and Marine Research, Bremerhaven, PANGAEA. https://doi.org/10.1594/ PANGAEA.834058. Accessed 20 Aug 2015

Gerdes D, Klages M, Arntz WE et al (1992) Quantitative investigations on macrobenthos communities of the southeastern Weddell Sea shelf based on multibox corer samples. Polar Biol 12:291-301

Gerdes D, Hilbig B, Montiel A (2003) Impact of iceberg scouring on macrobenthic communities in the high-Antarctic Weddell Sea. Polar Biol 26:295-301

Gleitz M, Bathmann EV, Lochte K (1994) Build-up and decline of summer phytoplankton biomass in the eastern Weddell Sea, Antarctica. Polar Biol 14:413-422

Graf G (1989) Benthic-pelagic coupling in a deep-sea benthic community. Nature 341:437-439

Graf G, Rosenberg R (1997) Bioresuspension and biodeposition: a review. J Mar Sys 11:269-278

Grant J, Bathmann EV (1987) Swept away: resuspension of bacterial mats regulates benthic-pelagic exchange of sulfur. Science 236:1472-1474. https://doi.org/10.1126/science.236.4807.1472

Gutt J (2001) On the direct impact of ice on marine benthic communities, a review. Polar Biol 24:553-564. https://doi.org/10.1007/ s003000100262

Gutt J, Starmans A (1998) Structure and biodiversity of megabenthos in the Weddell and Lazarev Seas (Antarctica): ecological role of physical parameters and biological interactions. Polar Biol 20:229-247

Gutt J, Starmans A, Dieckmann G (1998) Phytodetritus deposited on the Antarctic shelf and upper slope: its relevance for the benthic system. J Mar Syst 17:435-444

Gutt J, Barrat I, Domack E et al (2011) Biodiversity change after climate-induced ice-shelf collapse in the Antarctic. Deep-Sea Res II 58:74-83

Gutt J, Böhmer A, Dimmler W (2013a) Antarctic sponge spicule mats shape microbenthic diversity and act as a silicon trap. Mar Ecol Prog Ser 480:57-71. https://doi.org/10.3354/meps10226

Gutt J, Cape M, Dimmler W et al (2013b) Shifts in Antarctic megabenthic structure after ice-shelf disintegration in the Larsen area east of the Antarctic peninsula. Polar Biol 36:895-906. https://doi. org/10.1007/s00300-013-1315-7 
Hargrave BT (1973) Coupling carbon flow through some pelagic and benthic communities. J Fish Res Board Can 30:1317-1326

Hauck J, Hoppema M, Bellerby RGJ et al (2010) Data-based estimation of antropogenic carbon and acidification in the Weddell Sea on a decadal timescale. J Geophys Res 115:C03004. https://doi. org/10.1029/2009JC005479

Hauck J, Gerdes D, Hillenbrand C-D et al (2012) Distribution and mineralogy of carbonate sediments on Antarctic shelves. J Mar Syst 90:77-87. https://doi.org/10.1016/j.marsys.2011.09.005

Isla E (2016a) Environmental controls on sediment composition and particle fluxes over the Antarctic continental shelf. In: Beylich A, Dixon J, Zwoliński Z (eds) Source-to-sink fluxes in undisturbed cold environments. Cambridge University Press, Cambridge, pp 199-212. https://doi.org/10.1017/CBO9781107705791.017

Isla $\mathrm{E}$ (2016b) Organic carbon and biogenic silica in marine sediments in the vicinities of the Antarctic Peninsula: spatial patterns across a climatic gradient. Polar Biol 39:819-828. https://doi.org/10.1007/ s00300-015-1833-6

Isla E, Gerdes D, Palanques A et al (2006a) Particle fluxes and tides near the continental ice edge on the eastern Weddell Sea shelf. Deep-Sea Res II 53:866-874

Isla E, Gerdes D, Palanques A et al (2006b) Relationships between Antarctic coastal and Deep-sea particle fluxes: implications for the deep-sea benthos. Polar Biol 29:249-256

Isla E, Gerdes D, Palanques A et al (2009) Downward particle flux, wind and a phytoplankton bloom over a polar continental shelf: a stormy impulse for the biological pump. Mar Geol 259:59-72

Isla E, Gerdes D, Rossi S et al (2011) Biochemical characteristics of surface sediments on the Eastern Weddell Sea continental shelf, Antarctica: is there any evidence of seasonal patterns? Polar Biol 34:1125-1133

Jansen J, Hill NA, Dunstan PK et al (2018) Abundance and richness of key Antarctic seafloor fauna correlates with modelled food availability. Nat Ecol Evol 2:71-80. https://doi.org/10.1038/ s41559-017-0392-3

Kang S-H, Kang J-S, Lee S et al (2001) Antarctic phytoplankton assemblages in the marginal ice zone of the northwestern Weddell Sea. J Plankton Res 23(4):333-352

Kohlbach D, Lange BA, Schaafsma FL et al (2017) Ice algaeproduced carbon is critical for overwintering of Antarctic krill Euphausia superba. Front Mar Sci 4:310. https://doi.org/10.3389/ fmars.2017.00310

Ligowski R (2000) Benthic feeding by krill, Euphausia superba Dana, in coastal waters off West Antarctica and in Admiralty Bay, South Shetland Islands. Polar Biol 23:619-625

Lizotte MP (2001) The contribution of sea ice algae to Antarctic marine primary production. Am Zool 41(1):57-73. https://doi. org/10.1668/0003-1569(2001)041[0057:TCOSIA]2.0.CO;2

Luckenbach MR (1986) Sediment stability around animal tubes: the roles of hydrodynamic processes and biotic activity. Limnol Oceanogr 31:779-787

McClintic MA, DeMaster DJ, Thomas CJ et al (2008) Testing the FOODBANCS hypothesis: seasonal variations in near-bottom particle flux, bioturbation intensity, and deposit feeding based on ${ }^{234} \mathrm{Th}$ measurements. Deep-Sea Res II 55:2425-2437. https://doi. org/10.1016/j.dsr2.2008.06.003

Mercuri G, Tatián M, Momo F et al (2008) Massive input of terrigenous sediment into potter cove during austral summer and the effects on the bivalve Laternula elliptica: a laboratory experiment. Ber Polar Meeresforsch 571:111-117

Michels J, Dieckmann GS, Thomas DN et al (2008) Short-term biogenic particle flux under late spring sea ice in the western Weddell Sea. Deep-Sea Res II 55:1024-1039

Nicol S (2006) Krill, currents, and sea ice: Euphausia superba and its changing environment. Bioscience 56(2):111-120
Orejas C, Gile JM, López-Gonzélez J et al (2001) Feeding strategies and diet composition of four Antarctic cnidarian species. Polar Biol 24:620-627. https://doi.org/10.1007/s03000100272

Orvain F, Le Hir P, Sauriau P-G et al (2012) Modelling the effects of macrofauna on sediment transport and bed elevation: application over a cross-shore mudflat profile and model variation. Estuar Coastal Shelf Sci 108:64-75. https://doi.org/10.1016/j.ecss.2011.12.036

Palanques A, Isla E, Puig P et al (2002) Annual evolution of downward particle fluxes in the Western Bransfield Strait (Antarctica) during the FRUELA project. Deep-Sea Res II 49:903-920

Paterson DM (1989) Short-term changes in the erodibility of intertidal cohesive sediments related to the migratory behaviour of epipelic diatoms. Limnol Oceanogr 34:223-234

Pearse JS, McClintock JB, Bosch I (1991) Reproduction of Antarctic benthic marine invertebrates: tempos, modes, and timing. Am Zool 31(1):65-80

Piepenburg D (2016) Seabed photographs taken along OFOS profiles during Polarstern cruise PS96 (ANT-XXXI/2 FROSN). Alfred Wegener Institute, Helmholtz Center for Polar and Marine Research, Bremerhaven, PANGAEA. https://doi.org/10.1594/ PANGAEA.862097. Accessed 31 Oct 2016

Queirós AN, Stephens N, Cook R et al (2015) Can benthic community structure be used to predict the process of bioturbation in real ecosystems. Prog Oceanogr 137:559-569

Raffaelli D, Bell E, Weithoff G et al (2003) The ups and downs of benthic ecology: considerations of scale, heterogeneity and surveillance for benthic-pelagic coupling. J Exp Mar Biol Ecol 285-286:191203. https://doi.org/10.1016/S0022-0981(02)00527-0

Renaud PE, Morata N, Carroll ML et al (2008) Pelagic-benthic coupling in the western Barents Sea: processes and time scales. Deep-Sea Res II 55:2372-2380. https://doi.org/10.1016/j.dsr2.2008.05.017

Riebesell U, Schloss I, Smetack V (1991) Aggregation of algae released from melting sea ice: implications for seeding and sedimentation. Polar Biol 11:239-248

Rossi S, Isla E, Martínez-García A et al (2013) Transfer of seston lipids during a flagellate bloom from the surface to the benthic community in the Weddell Sea. Sci Mar 77(3):397-407. https://doi.org/10.3989/ scimar.03835.30A

Sañé E, Isla E, Grémare A et al (2011) Pigments in sediments beneath recently collapsed ice shelves: the case of Larsen A and B shelves, Antarctic peninsula. J Sea Res 65:94-102

Sañé E, Isla E, Gerdes D et al (2012) Benthic macrofauna assemblages and biochemical properties of sediments in two Antarctic regions differently affected by climate change. Cont Shelf Res 35:53-63

Schaafsma FL, Kohlbach D, David C et al (2017) Spatio-temporal variability in the winter diet of larval and juvenile Antarctic krill, Euphausia superba, in ice-covered waters. Mar Ecol Prog Ser 580:101-115. https://doi.org/10.3354/meps 12309

Scharek R, Smetacek V, Fahrbach E et al (1994) The transition from winter to early spring in the eastern Weddell Sea, Antarctica: plankton biomass and composition in relation to hydrography and nutrients. Deep-Sea Res I 41(8):1231-1250

Schmidt K, Atkinson A, Steigenberger S et al (2011) Seabed foraging by Antarctic krill: implications for stock assessment, benthopelagic coupling, and the vertical transfer of iron. Limnol Oceanogr 56(4):1411-1428. https://doi.org/10.4317/lo.2011.56.4.1411

Schnack-Schiel SB, Isla E (2005) The role of zooplankton in the pelagicbenthic coupling of the Southern Ocean. Sci Mar 69(2):39-55

Sedwick PN, DiTullio G (1997) Regulation of algal blooms in Antarctic shelf waters by the release of iron from melting sea ice. Geophys Res Lett 24(20):2515-2518

Sedwick P, DiTullio GR, Mackey DJ (2000) Iron and manganese in the Ross Sea, Antarctica: seasonal iron limitation in Antarctic shelf waters. J Geophys Res 105(C5):11321-11336 
Segelken-Voigt A, Bracher A, Dorschel B et al (2016) Spatial distribution patterns of ascidians (Ascidiacea: Tunicata) on the continental shelves off the northern Antarctic Peninsula. Polar Biol 39:863-879. https://doi.org/10.1007/s00300-016-1909-y

Self RFL, Nowell ARM, Jumars PA (1989) Factors controlling critical shears for deposition and erosion of individual grains. Mar Geol 86:181-199

Smith CR, Minks S, DeMaster DJ (2006) A synthesis of bentho-pelagic coupling on the Antarctic shelf: food banks, ecosystem inertia and global climate change. Deep-Sea Res II 53:875-894. https://doi. org/10.16/j.dsr2.2006.02.001

Smith CR, Mincks S, DeMaster DJ (2008) The FOODBANCS project: introduction and sinking fluxes of organic carbon, chlorophyll- $a$ and phytodetritus on the western Antarctic Peninsula continental shelf. Deep-Sea Res II 55:2404-2414

Souster TA, Morley SA, Peck LS (2018) Seasonality of oxygen consumption in five common Antarctic benthic marine invertebrates. Polar Biol 41(5):897-908. https://doi.org/10.1007/ s00300-018-2251-3
Stanwell-Smith D, Peck LS, Clarke A et al (1999) The distribution, abundance and seasonality of pelagic marine invertebrate larvae in the maritime Antarctic. Philos Trans R Soc B 354:471-484

Sumida PYG, Bernardino AF, Stedall VP et al (2008) Temporal changes in benthic megafaunal abundance and composition across the West Antarctic Peninsula shelf: results from video surveys. Deep-Sea Res II 55:2465-2477

Sumida PYG, Smith CR, Bernardino AF et al (2014) Seasonal dynamics of megafauna on the deep West Antarctic Peninsula shelf in response to variable phytodetrital influx. R Soc Open Sci 1:140294. https://doi.org/10.1098/rsos.140294

Tarling GA, Johnson ML (2006) Satiation gives krill that sinking feeling. Curr Biol 16:R83-R84. https://doi.org/10.1016/j.cub.2006.01.044

Tatián M, Mercuri G, Fuentes VL et al (2008) Role of benthic filter feeders in pelagic-benthic coupling: assimilation, biodeposition and particle flux. Ber Polar Meeresforsch 571:118-127

Thomas DN, Dieckmann GS (2002) Antarctic Sea ice - a habitat for extremophiles. Science 295(5555):641-644. https://doi. org/10.1126/science.1063391

Open Access This chapter is licensed under the terms of the Creative Commons Attribution 4.0 International License (http://creativecommons. org/licenses/by/4.0/), which permits use, sharing, adaptation, distribution and reproduction in any medium or format, as long as you give appropriate credit to the original author(s) and the source, provide a link to the Creative Commons license and indicate if changes were made.

The images or other third party material in this chapter are included in the chapter's Creative Commons license, unless indicated otherwise in a credit line to the material. If material is not included in the chapter's Creative Commons license and your intended use is not permitted by statutory regulation or exceeds the permitted use, you will need to obtain permission directly from the copyright holder. 